Mirna Leko Šimić

Josip Juraj Strossmayer

University of Osijek

Faculty of Economics in Osijek

31000 Osijek, Croatia

lekom@efos.hr
Ana Pap

Josip Juraj Strossmayer

University of Osijek

Faculty of Economics in Osijek

31000 Osijek, Croatia

ana.pap@efos.hr
JEL: $M 30$

Original scientific paper

https://doi.org/10.51680/ev.34.2.9

Received: April 22, 2021

Revision received: July 26, 2021

Accepted for publishing: July 28, 2021

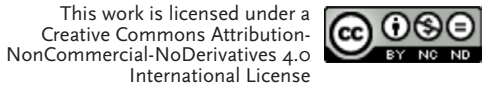

\title{
GENERATION Z BUYING BEHAVIOR CHANGE IN THE COVID-19 PANDEMIC CONTEXT
}

\section{Abstract}

Purpose: The purpose of this research is to analyze the changes in Croatian Generation Z buying behavior due to the COVID-19 pandemic. As a result of the pandemic, all governments have imposed different measures that directly and indirectly impact consumer behavior. Recent studies have mostly recorded a dynamic increase in online shopping, stockpiling, and change in priorities from luxury to basic goods. This study will specifically look into the relation between Generation Z buying behavior change and their exposure to the COVID-19 pandemic as well as its impact on their perception of the quality of life.

Methodology: A sample of 442 Generation $\mathrm{Z}$ respondents from Croatia was analyzed using ANOVA to identify buying behavior changes concerning the level of their exposure to COVID-19. The analysis also included a potential correlation between buyer behavior change and their perception of the quality of life.

Results: The statistical analysis has confirmed the increase of online shopping and stockpiling in the group of respondents who were exposed to self-isolation and those who have not been exposed to COVID-19, but there was no correlation with their perception of the quality of life change as a result of forced buying behavior change.

Conclusion: Generation $\mathrm{Z}$ is identified as an e-generation, born and brought up in a digital environment. Although the pandemic has forced them to switch even more to online shopping, they do not perceive the exposure to the COVID-19 pandemic to impact their quality of life.

Keywords: Generation Z, COVID-19, buying behavior, quality of life, Croatia

\section{Introduction}

Consumer behavior changes are often the result of positive or negative externalities. The most significant contemporary negative externality is the COVID-19 pandemic. To control the pandemic, most governments have imposed different measures that directly and indirectly impact consumer behavior. Moreover, consumers themselves are changing their attitudes, priorities, opinions and behaviors due to the pandemic and related health concerns. Several studies (Laato et al., 2020; Hall et al., 2021; Donthu \& Gustafsson, 2020; Kirk \& Rifkin, 2020) have already confirmed the changes in consumer behavior that are related to the COVID-19 pandemic. Most of these changes are reflected in 
a dynamic increase of online compared to physical shopping (Ali, 2020; Mason et al., 2020; Donthu \& Gustafsson, 2020) and in the change in priorities from luxury to basic products (Kirk \& Rifkin, 2020; Aksoy \& Ergen, 2020).

The aim of this study is to get an insight into the changes in the Croatian Generation Z consumer behavior due to the COVID-19 pandemic. Some studies have recognized the generational differences in perception of life and consumer behavior related to the COVID-19 pandemic (Life with Corona Network, 2020; Masters et al., 2020). There is a perception that a large swath of millennials and Generation $\mathrm{Z}$ are not heeding the public health cry of concern. Some young people seem to be continuing to live life as normal (Gharzai et al., 2020; Baus, 2021).

Generation Z, the students of today, is already identified as an e-generation born and brought up in a digital environment. As they were born with technology, they are connected with others through technology at all times and they have FOMO, or the "fear of missing out" (Chareewan et al., 2020). According to Hope (2016) Generation Z is realistic, social change-oriented, and self-confident. They rely on and believe in online information accuracy. In terms of buying behavior, Generation $\mathrm{Z}$ is a generation that craves immediate action, is impatient and moves without much hesitation from one offering to another (Bencsik et al., 2016).

This study looks more specifically into the relation between the behavior change of the Croatian Generation $\mathrm{Z}$ with respect to their exposure to the COVID-19 pandemic (no exposure, light exposure, heavy exposure) and their perceptions on its impact on their quality of life.

\section{Literature overview and hypothesis development}

Times of crisis, like the COVID-19 pandemic, create changes in many aspects of human life. From a behavioral perspective, the pandemic can be viewed as a collective action problem in which the success of the group - a region, a country, or the whole of humanity - depends on individual actions (BrañasGarza et al., 2020). Some authors (Mason et al., 2020) identify the COVID-19 pandemic as an economic catalyst capable of altering the economy as well as consumer behaviors. Generally, it is possible to summarize the consumers' purchasing behaviors in times of crisis as follows (Hayta, 2012, p. 20):

- decrease in total consumption and wastefulness,

- extended information research on products,

- substitution with cheaper brands,

- buying local products rather than foreign brands,

- preference of informative ads over visual ads,

- intense interest in discounted stores and promotional goods.

Some authors (Agarwal \& Singh, 2021) add the simplification of demand patterns due to limited offerings and discounts during the pandemic. A study by Nicomedes and Avila (2020) has shown that symptoms of hypochondriasis increase as people get in closer proximity with COVID-19 patients. It can be assumed that hypochondriasis will also influence consumer behavior - the study has identified the avoidance of crowded places (like shops) and social activities in general, increased consumption of hygiene and disinfection products as well as canned and durable food products.

A study of US consumers (Mason et al., 2020) suggests that the COVID-19 pandemic has altered consumers' product needs, shopping behaviors, purchasing behaviors as well as their post-purchase satisfaction levels: consumers are avoiding publicly consumed products and have increased their virtual shopping and online purchasing behaviors. Consumers satisfaction levels have decreased and it is more difficult for marketers to gain customer loyalty.

Therefore, the following hypothesis has been developed:

\section{H1: There is a statistically significant difference between consumer behavior change in Croatian Generation $Z$ with respect to their exposure to the COVID-19 pandemic.}

It is assumed that those hit "harder" by the COVID-19 pandemic, i.e. having more serious exposure themselves and/or in their family and friends, will change their behavior more than those who have no direct or indirect experience with the pandemic.

Consumer spending has fallen across America and Europe since the beginning of the Corona crisis. Consumption levels have fallen by 25 percent in Europe, especially since mid-March in the UK, France, Spain, and Italy. At the same time, the con- 
sumption in the US. decreased by $10 \%$. Globally, consumers still spend (and sometimes more) on home entertainment as well as basic products such as food, household items, and personal care items. However, they significantly withdraw voluntary expenditure in most countries except China. Some of the fastest decreasing categories include restaurants, clothing, shoes, jewelry, accessories, travel, and outside entertainment (Aksoy \& Ergen, 2020). Besides the shifts in product preference, changed and/or limited access to a number of social goods (education, health, etc.) can be interpreted as quality of life deterioration. A global study (Life with corona, 2020) has found that younger people, especially Generation $\mathrm{Z}$, are significantly harder hit by all three aspects of the pandemic: social, emotional, and economic. A few studies have indicated that being a student and being younger than 35 (mostly Generation Z) is associated with a stronger impact on the decreasing quality of life perception (Wang et al., 2020; Liu et al., 2020; Sønderskov et al., 2020). Therefore, the second hypothesis is:

H2: There is a statistically significant difference in the perception of life quality change in Croatian Generation $Z$ with respect to their exposure to COVID-19.

Other than only testing the difference in the perception of life quality change with respect to the exposure to COVID-19, it is interesting to see whether changes in buying behavior are correlated with the perception of life quality change. The third hypothesis is:

H3: Significant changes in consumer behavior of Croatian Generation $Z$ enforced by the COVID-19 pandemic are correlated with their perceived quality of life.

It is assumed here that those who have, due to the COVID-19 pandemic, changed their buying behavior more, will also show changes in their perception of life quality.

\section{Methodology}

A COVID-19 and youth project was created with university students of the Croatian university who participated in online research. The students were encouraged and incentivized to recruit further participants to obtain a richer subject pool in terms of geographical and other characteristics. Neither participation nor recruitment was com- pulsory. Those who participated $(\mathrm{n}=30)$ recruited other participants from all Croatian regions. Our procedures resulted in a final sample of 442 Croatian participants aged $18-25$, of which $76.1 \%$ were females. More details on the sample are given in Table 1.

\section{Table 1 Sample description}

\begin{tabular}{|c|c|c|}
\hline & $\mathbf{N}$ & $\%$ \\
\hline \multicolumn{3}{|l|}{ Gender } \\
\hline Male & 104 & 23.9 \\
\hline Female & 332 & 76.1 \\
\hline \multicolumn{3}{|l|}{ Year of study } \\
\hline 1 & 73 & 16.7 \\
\hline 2 & 55 & 12.6 \\
\hline 3 & 91 & 20.9 \\
\hline 4 & 111 & 25.5 \\
\hline 5 & 88 & 20.2 \\
\hline \multicolumn{3}{|l|}{ Place of residence } \\
\hline City/town & 332 & 76.1 \\
\hline Village & 81 & 18.6 \\
\hline Suburbs & 21 & 4.8 \\
\hline \multicolumn{3}{|l|}{ Household income } \\
\hline Up to $5000 \mathrm{HRK}$ & 80 & 18.3 \\
\hline $5001-7500 \mathrm{HRK}$ & 93 & 21.3 \\
\hline 7501 - 10000 HRK & 113 & 25.9 \\
\hline 10001 - $15000 \mathrm{HRK}$ & 85 & 19.5 \\
\hline More than $15000 \mathrm{HRK}$ & 65 & 14.9 \\
\hline
\end{tabular}

Source: Authors

Since this study tries to see the impact of COVID-19 exposure on consumer behavior change, three levels of exposure have been predefined: no direct exposure, meaning that neither the respondent nor anyone in his/her close family and friends circles was exposed to COVID-19, light exposure, where the respondent or some members of his/her family and/or friends were ill, but with light symptoms and could handle the illness at home or were in self-isolation, and hard exposure, where respondents and/or their family member or friends have developed a more complicated type of the disease, had to be hospitalized or have died. Table 2 depicts respondents' level of exposure to COVID-19. 
Table 2 Respondents' level of exposure to COVID-19

\begin{tabular}{|l|c|}
\hline \multicolumn{1}{|c|}{ Personal level of exposure to COVID-19 } & $\%$ \\
\hline Respondents who have been in self-isolation. & 13.3 \\
\hline Respondents who have overcome the disease with mild symptoms (home treatment). & 7.1 \\
\hline Respondents who have overcome the disease with more complicated symptoms (hospital treatment). & 0.5 \\
\hline Respondents who had no personal exposure to COVID-19. & 79.1 \\
\hline \multicolumn{1}{|c|}{ Level of exposure to COVID-19 of respondents' close family/friends } & 26.8 \\
\hline Respondents' close family/friends have been in self-isolation. & 37.4 \\
\hline Respondents' close family/friends have overcome the disease with mild symptoms (home treatment). & 3.2 \\
\hline $\begin{array}{l}\text { Respondents' close family/friends have overcome the disease with more complicated symptoms (hospital } \\
\text { treatment). }\end{array}$ & 1.1 \\
\hline Respondents' close family/friends have died from the disease. & 31.4 \\
\hline Respondents' close family/friends had no exposure to COVID-19. & \\
\hline
\end{tabular}

Source: Authors

After conducting the research and obtaining all the necessary data, it was processed and analyzed using the Statistical Package for the Social Sciences (SPSS). The ANOVA test was used to identify statistically significant differences between the increase in online shopping and the level of exposure to the COVID-19 pandemic.

\section{Results and discussion}

To test H1, the ANOVA test was used. The results have shown some differences in buying behavior change in Generation Z, but altogether they were significantly lower than expected. Three types of changes in shopping behavior were tested: increase of online shopping, decrease of offline shopping and stockpiling.

Table 3 Differences in online shopping increase with respect to exposure to COVID-19 (ANOVA)

\begin{tabular}{|c|c|c|c|c|c|}
\hline \multicolumn{6}{|c|}{ ANOVA } \\
\hline & Sum of Squares & df & Mean Square & $\mathbf{F}$ & Sig. \\
\hline Between Groups & 6.335 & 3 & 2.112 & 3.165 & .024 \\
\hline Within Groups & 287.543 & 431 & .667 & & \\
\hline Total & 293.877 & 434 & & & \\
\hline
\end{tabular}

Source: Authors

Table 4 Differences in online shopping increase with respect to exposure to COVID-19 (descriptive analysis)

\begin{tabular}{|l|r|r|r|c|}
\hline & N & Mean & Std. Deviation & Std. Error \\
\hline Self-isolation & 58 & $1.8506^{*}$ & .92859 & .12193 \\
\hline Had COVID-19 (home treatment) & 31 & 1.7204 & .89896 & .16146 \\
\hline Had COVID-19 (hospital treatment) & 2 & 1.6667 & .94281 & .66667 \\
\hline Not exposed to COVID-19 & 344 & $1.5145^{*}$ & .78851 & .04251 \\
\hline Total & $\mathbf{4 3 5}$ & $\mathbf{1 . 5 7 4 7}$ & $\mathbf{. 8 2 2 8 8}$ & .03945 \\
\hline
\end{tabular}

* statistically significant difference $(\mathrm{p}<0.05)$

Source: Authors 
The results of the ANOVA analysis and Bonferroni's post hoc test have shown a statistically significant difference in the increase of online shopping between those respondents who were mildly exposed to COVID-19 (self-isolation) and those who were not exposed to COVID-19. This is quite logical, since self-isolation has forced many families to turn to online shopping, even for daily supplies. These results correspond to global trends identified in several studies: they have been recorded in India (Agarwal \& Singh, 2021), Greece (Theodoridis \& Kavoura, 2021), Italy (Amatulli, et al., 2021; Ali Taha et al., 2021), Slovakia (Ali Taha et al., 2021), and many other countries worldwide.

However, there was no statistically significant change in the decrease of offline shopping with respect to the level of COVID-19 exposure, which is illustrated in Table 5.

Table 5 Differences in offline shopping decrease with respect to exposure to COVID-19 (ANOVA)

\begin{tabular}{|l|r|r|r|r|r|}
\hline \multicolumn{7}{|c|}{ ANOVA } & F & Sig. \\
\hline & Sum of Squares & df & Mean Square & .610 & .609 \\
\hline Between Groups & 2.773 & 3 & .924 & & \\
\hline Within Groups & 652.559 & 431 & $\mathbf{6 5 1 4}$ & & \\
\hline
\end{tabular}

Source: Authors

This finding can probably be explained by specific characteristics of Generation Z regarding their buying habits: Generation $\mathrm{Z}$ is a young, technology-oriented group in retailing, since they use their smartphones and other technologies very extensively for shopping (Bernstein, 2015). She calls them "digital natives" to emphasize the role of digital in their shopping behavior. A study by Priporas et al. (2017) also concludes that Generation $\mathrm{Z}$ customers are heavy online shoppers. Therefore, they probably do not perceive their already infrequent physical shopping activities to have further declined.

The third buying behavior change tested, stockpiling, has shown a statistically significant difference between those who were mildly exposed to COVID-19 and those who were not (Tables 6 and 7). Those respondents who have experienced self-isolation have stockpiled significantly more than those who were not (results of Bonferroni's post hoc test).

Table 6 Differences in stockpiling practice with respect to exposure to COVID-19 (ANOVA)

\begin{tabular}{|l|r|r|r|r|r|}
\hline \multicolumn{7}{|c|}{ ANOVA } \\
\hline & Sum of Squares & df & Mean Square & F & Sig. \\
\hline Between Groups & 10.658 & 3 & 3.553 & 2.751 & .042 \\
\hline Within Groups & 556.539 & 431 & 1.291 & & \\
\hline Total & $\mathbf{5 6 7 . 1 9 8}$ & $\mathbf{4 3 4}$ & & & \\
\hline
\end{tabular}

Source: Authors

Table 7 Differences in stockpiling practice with respect to exposure to COVID-19 (descriptive analysis)

\begin{tabular}{|l|r|r|r|r|}
\hline & N & Mean & Std. Deviation & Std. Error \\
\hline Self-isolation & 58 & $2.1466^{*}$ & 1.23902 & .16269 \\
\hline Had COVID-19 (home treatment) & 31 & 1.9516 & 1.32511 & .23800 \\
\hline Had COVID-19 (hospital treatment) & 2 & 1.0000 & .00000 & .00000 \\
\hline Not exposed to COVID-19 & 344 & $1.7297^{*}$ & 1.10176 & .05940 \\
\hline Total & $\mathbf{4 3 5}$ & $\mathbf{1 . 7 9 7 7}$ & $\mathbf{1 . 1 4 3 2 0}$ & .05481 \\
\hline
\end{tabular}

* statistically significant difference $(\mathrm{p}<0.05)$

Source: Authors 
Some studies on stockpiling during the COVID-19 pandemic indicate that consumer behavior is different regarding the timeline of the pandemic: In its early stages, consumer behavior was very similar to the one found in previous negative externalities of similar type and lead to stockpiling (Loxton et al., 2020; Hall et al., 2021), while the ongoing uncertainty evoked by the pandemic may lead to transformative consumption patterns in the long term (Kirk \& Rifkin, 2020). Since this study was conducted in a relatively early phase of the pandemic, it shows that stockpiling was typical behavior of those who experienced self-isolation.

According to the obtained results, it seems that the most changes in Generation $\mathrm{Z}$ buying behavior have occurred in the group who had to be in self-isolation (usually for two weeks). Their behav- ior was probably determined by fear of getting ill (themselves or their contacts) and associated perceived risk, at least for the near future. On the other hand, those who had COVID-19 felt that they are safe for the future and turn to "normal" life and behavior. $\mathrm{H} 1$ is, therefore, only partially accepted.

The ANOVA test was used to test H2. When analyzing the difference in the perception of change of the quality of life with respect to their own exposure to COVID-19, no significant differences were found $(p=0.525)$. The perception of change of the quality of life due to the "new normal" has been measured with Likert's 1-5 scale (1 - "new normal" has not changed the quality of my life at all, 5 "new normal" has changed the quality of my life for the worse a lot). The descriptive analysis is shown in Table 8.

Table 8 Descriptive statistics for the perception of change in life quality - Croatian Generation $Z$ respondents' level of exposure to COVID-19

\begin{tabular}{|l|r|r|r|r|}
\hline & \multicolumn{1}{|c|}{$\mathrm{N}$} & \multicolumn{1}{c|}{ Mean } & \multicolumn{1}{c|}{ Std. Deviation } & \multicolumn{1}{c|}{ Std. Error } \\
\hline Self-isolation & 51 & 3.569 & 1.3906 & .1826 \\
\hline Had COVID-19 (home treatment) & 38 & 3.774 & 1.2572 & .2258 \\
\hline Had COVID-19 (hospital treatment) & 2 & 2.500 & 2.1213 & 1.5000 \\
\hline Not exposed to COVID-19 & 344 & 3.703 & 1.3223 & .0713 \\
\hline Total & $\mathbf{4 3 5}$ & $\mathbf{3 . 6 8 5}$ & $\mathbf{1 . 3 2 8 4}$ & $\mathbf{. 0 6 3 7}$ \\
\hline
\end{tabular}

Source: Authors

Also, analyzing the level of exposure to COVID-19 of family/friends close to respondents, no signifi-

cant differences have been found $(\mathrm{p}=0.124)$. Results of the descriptive analysis are shown in Table 9.

Table 9 Descriptive statistics for the perception of change in life quality - Croatian Generation Z' close family/friends' level of exposure to COVID-19

\begin{tabular}{|l|c|c|c|c|}
\hline & $\mathrm{N}$ & Mean & Std. Deviation & Std. Error \\
\hline $\begin{array}{l}\text { Respondents whose close family/friends have been in } \\
\text { self-isolation. }\end{array}$ & 117 & 3.803 & 1.2334 & .1140 \\
\hline $\begin{array}{l}\text { Respondents whose close family/friends have overcome } \\
\text { the disease with mild symptoms (home treatment). }\end{array}$ & 163 & 3.730 & 1.3197 & .1034 \\
\hline $\begin{array}{l}\text { Respondents whose close family/friends have overcome } \\
\text { the disease with more complicated symptoms (hospital } \\
\text { treatment). }\end{array}$ & 14 & 4.143 & 1.2315 & .3291 \\
\hline $\begin{array}{l}\text { Respondents whose close family/friends have died from } \\
\text { the disease. }\end{array}$ & 5 & 4.200 & .4472 & .2000 \\
\hline $\begin{array}{l}\text { Respondents whose close family/friends had no exposu- } \\
\text { re to COVID-19 pandemic. }\end{array}$ & 137 & 3.467 & $\mathbf{4 3 6}$ & .1213 \\
\hline Total & $\mathbf{4 3 6 8 6}$ & $\mathbf{1 . 3 2 7 0}$ & $\mathbf{0 6 3 5}$ \\
\hline
\end{tabular}

Source: Authors 
As expected and in line with the Life with corona network study (2020), Generation Z perceives their quality of life decreasing due to imposed measures that have forced them to change their buying behavior. However, there are no significant differences between their perceived quality of life decrease in relation to their level of exposure to COVID-19 or the level of exposure of people close to them. It is different from a few other studies, the most extreme case being Lim's (2020) research, which has found $71 \%$ of Generation $\mathrm{Z}$ respondents in Asia Pacific region stating that the economic fallout of COVID-19 negatively affects their mental health and well-being.

Based on the results obtained, $\mathrm{H} 2$ has not been accepted. However, the results of descriptive statistics show that respondents whose close contacts were exposed to COVID-19 express a higher level of perceived decrease of life quality.

To test H3, whether there is a correlation between buying behavior change and perceived life quality change, a correlation analysis has been performed. Variables that describe buying behavior change, namely "increase in online shopping", "decrease in offline shopping" and "stockpiling", have each been correlated with the variable "change in life quality". The results have shown that there were no statistically significant correlations between the increase in online shopping and the change in life quality perception ( $\mathrm{p}=0.852)$. Also, no correlation has been found between the decrease in offline shopping and the change in life quality perception $(\mathrm{p}=0.461)$. Finally, correlating stockpiling and change in the quality of life also showed no significant correlations $(p=0.903)$. It can be concluded that changes in buying behavior of Croatian Generation $\mathrm{Z}$ do not correlate with their perceptions of change in the quality of life, so H3 is not accepted.

\section{Conclusion}

This research offers original findings on shifts in Croatian Generation $\mathrm{Z}$ consumers' behaviors and their implications for their quality of life perceptions. The results have shown that their buying behavior has changed in relation to their exposure to COVID-19 in some aspects. Croatian Generation $\mathrm{Z}$ respondents who have self-isolated due to the
COVID-19 pandemic have said that they buy more online than they did before the pandemic compared to those who have not been directly exposed to COVID-19. The general increase in online shopping seems to be a global trend, and Croatian Generation Z, according to this study, follows the trend. But, when it comes to decreased offline shopping, the results have shown that Croatian Generation $\mathrm{Z}$ does not show any statistically significant differences in relation to their exposure to COVID-19. Since they were identified as heavy online shoppers even before the pandemic, they probably do not perceive their already infrequent physical shopping activities to have further declined. When it comes to stockpiling as a buying behavior change, the results have shown that respondents who have experienced selfisolation stockpile significantly more than those who have not been affected by the virus at all.

According to the results of this research, it seems that the most changes in Generation $\mathrm{Z}$ buying behavior have occurred in the group who had to selfisolate (usually for two weeks). Their behavior was probably determined by fear of getting ill, while on the other hand, those who had COVID-19 perceive that they are safe for the future and turned to their normal behavior.

When it comes to the change in the perception of their quality of life, it is evident that Generation $\mathrm{Z}$ perceives that their quality of life has decreased, but with no statistically significant differences between the levels of exposure to COVID-19. The lack of difference between groups can be explained by the general perception of life quality decrease. Even the people who have not been infected with the virus have expressed that their quality of life has changed for the worse. This is probably the result of numerous measures implemented to control and stop the pandemic (reduced social contacts, closing the stores, restaurants and cafes, postponing concerts and other cultural events, etc.). However, the perception of the decrease in life quality shows no correlation with the changes in buying behavior so it is evident that changes in buying behavior could not be the reason for the decreased quality of life. It could be expected that these changed buying behaviors could remain even after the pandemic is over and become the standard new normal behavior for Generation Z. 
The limitation of this study is determined by the sample which is not fully representative. For this reason, the results of this study can only be taken as indicative. Future research should investigate buying behavior changes that have occurred as a consequence of the COVID-19 pandemic in Generation $\mathrm{Z}$ in more detail. For example, it would be interest- ing to study future intentions in buying behavior and predict changes that are going to be adopted by Generation $\mathrm{Z}$ and retained even after the pandemic ends. Moreover, since several studies have indicated that there are generational differences, it would be of interest to compare results on consumer behavior changes for other generations. 


\section{REFERENCES}

1. Agarwal, S. \& Singh, A. (2021). Consumer behavioral change during COVID 19. In Khuntia, J. \& Kaur, S. (Eds.), Impact of COVID 19 on different sectors of Indian Economy (pp. 163-173), Academic Publication Delhi.

2. Aksoy, C. \& Ergen, A. (2020). Changes in consumer behaviour of gen Y'ers in COVID-19 PANDEMIC. Aurum Sosyal Bilimler Dergisi, 5(2), 127-147.

3. Ali, I. (2020). The COVID-19 Pandemic: Making Sense of Rumor and Fear. Medical Anthropology, 39(5), 376-379. https://doi.org/10.1080/01459740.2020.1745481

4. Ali Taha, V., Pencarelli, T., Škerháková, V., Fedorko, R. \& Košíková, M. (2021). The Use of Social Media and Its Impact on Shopping Behavior of Slovak and Italian Consumers during COVID-19 Pandemic. Sustainability, 13(4), 1-19. https://doi.org/10.3390/su13041710

5. Amatulli, C., Peluso, A. M., Sestino, A., \& Guido, G. (2021). New consumption orientations in the COVID-19 era: Preliminary findings from a qualitative investigation. In Andreani, J.-C. \& Collesei, U. (Eds.). Proceedings from 20th International Marketing Trends Conference. Paris-Venice: Marketing Trends Association.

6. Baus, V. (2021). Psihologinja brani mlade: 'Taman kad pohvataju kako se trebaju ponašati, vide da se oni koji bi im trebali biti uzor ne pridržavaju mjera". https://dnevnik.hr/vijesti/koronavirus/psihologinjaobjasnjava-da-kako-ce-se-mladi-pridrzavati-mjera-ako-od-odraslih-vide-da-iste-krse---639038.html

7. Bencsik, A., Horvath-Csikos, G. \& Juhasz, T. (2016). Y and Z Generations at Workplaces. Journal of Competitiveness, 8(3), 90-106. https://doi.org/10.7441/joc.2016.03.06

8. Bernstein, R. (2015). Move over millennials - here comes Gen Z. Adage. https://adage.com/article/cmo-strategy/move-millennials-gen-z/296577

9. Brañas-Garza, P., Jorrat, D. A., Alfonso, A., Espin, A. M., Garcia, T. \& Kovarik, J. (2020). Exposure to the COVID-19 pandemic and generosity. https://mpra.ub.uni-muenchen.de/103389/1/MPRA_paper_103389.pdf. https://doi.org/10.31234/osf.io/6ktuz

10. Chareewan, S., Grunhagen, M., Pološki Vokić, N. \& Dlačić, J. (2020). Differences in Work Expectations of Generation Y and Generation Z: An Empirical Investigation in Croatia. Journal of Business, Industry and Economics, 25(Spring), 1-32.

11. Donthu, N. \& Gustafsson, A. (2020). Effects of COVID-19 on business and research, Journal of Business Research, 117, 284-289. https://doi.org/10.1016/j.jbusres.2020.06.008

12. Gharzai, L. A., Beeler, W. H. \& Jagsi, R. (2020). Playing into stereotypes: engaging Millennials and generation $\mathrm{Z}$ in the COVID-19 pandemic response. Advances in Radiation Oncology, 5(4), 679-681. https://doi.org/10.1016/j.adro.2020.04.009

13. Hall, M. C., Prayag, G., Fieger, P. \& Dyason, D. (2021). Beyond panic buying: Consumption displacement and COVID-1. Journal of Service Management, 32(1), 113-128.

https://doi.org/10.1108/JOSM-05-2020-0151

14. Hayta, A. B. (2012). Ekonomisi, A. Ekonomik Krizin Tüketicilerin Satın Alma Davranışı Üzerine Etkileri. Tüketici Yazıları.

15. Hope, J. (2016). Get your campus ready for Generation Z, Student Affairs Today, 19(7), 1-7. https://doi.org/10.1002/say.30253

16. Kirk, C. P. \& Rifkin, L. S. (2020). I'll trade you diamonds for toilet paper: Consumer reacting, coping and adapting behaviors in the COVID-19 pandemic. Journal of Business Research, 117, 124-131. https://doi.org/10.1016/j.jbusres.2020.05.028

17. Laato, S., Najmul Islam, A. K. M., Farooq, A. \& Dhir A. (2020). Unusual purchasing behavior during the early stages of the COVID-19 pandemic: The stimulus-organism-response approach. Journal of Retailing and Consumer Services, 57. https://doi.org/10.1016/j.jretconser.2020.102224 
18. Life with corona network (2020). Research Report: Shared global sentiments and generational divides. ISDC. www.lifewithcorona.org

19. Lim, S. (2020). Gen $z$ in APAC say their mental health has been impacted by COVID-19. https://www. thedrum.com/news/2020/10/10/gen-z-apac-say-their-mental-health-has-been-impacted-COVID-19.

20. Liu, N., Zhang, F., Wei, C., Jia, Y., Shang, Z., Sun, L., ... \& Liu, W. (2020). Prevalence and predictors of PTSS during COVID-19 outbreak in China hardest-hit areas: Gender differences matter. Psychiatry Research, 287. https://doi.org/10.1016/j.psychres.2020.112921

21. Loxton, M., Truskett, R., Scarf, B., Sindone, L., Baldry, G. \& Zhao, Y. (2020). Consumer Behaviour during Crises: Preliminary Research on How Coronavirus Has Manifested Consumer Panic Buying, Herd Mentality, Changing Discretionary Spending and the Role of the Media in Influencing Behaviour. Journal of Risk and Financial Management, 13(8), 1-21. https://doi.org/10.3390/jrfm13080166

22. Mason, A., Narcum, J. \& Mason, K. (2020). Changes in consumer decision-making resulting from the COVID-19 pandemic. Journal of Customer Behaviour, 19(2), 299-321. https://doi.org/10.1362/147539220X16003502334181

23. Masters N. B., Shih S-F., Bukoff, A., Akel, K. B., Kobayashi, L. C., Miller, A. L., Harapan, H., Lu, Y \& Wagner, A. L. (2020). Social distancing in response to the novel coronavirus (COVID-19) in the United States. PLoS ONE, 15(9). https://doi.org/10.1371/journal.pone.0239025

24. Nicomedes, C. J. C. \& Avila, R. M. A. (2020). An analysis on the panic during COVID-19 pandemic through an online form. Journal of Affective Disorders, 276, 14-22.

https://doi.org/10.1016/j.jad.2020.06.046

25. Priporas, C. V., Stylos, N. \& Fotiadis, A. K. (2017). Generation Z consumers' expectations of interactions in smart retailing: A future agenda. Computers in Human Behavior, 77, 374-381. https://doi.org/10.1016/j.chb.2017.01.058

26. Sønderskov, K. M., Dinesen, P. T., Santini, Z. I., \& Østergaard, S. D. (2020). The depressive state of Denmark during the COVID-19 pandemic. Acta Neuropsychiatrica, 32(4), 226-228. https://doi.org/10.1017/neu.2020.15

27. Theodoridis, P. K. \& Kavoura, A. (2021). The Impact of COVID-19 on Consumer Behaviour: The Case of Greece. In Kavoura, A., Havlovic, S. J. \& Totskaya, N. (Eds.), Strategic Innovative Marketing and Tourism in the COVID-19 Era (p. 11). Springer Nature. https://doi.org/10.1007/978-3-030-66154-0_2

28. Wang, C., Pan, R., Wan, X., Tan, Y., Xu, L., Ho, C. S. \& Ho, R. C. (2020). Immediate psychological responses and associated factors during the initial stage of the 2019 coronavirus disease (COVID-19) epidemic among the general population in China. International journal of environmental research and public health, 17(5), 1729. https://doi.org/10.3390/ijerph17051729 